PERM JOURNAL OF PETROLEUM AND MINING ENGINEERING

ВЕСТНИК ПНИІУ. ГЕОЛОГИЯ. НЕФТЕААЗОВОЕ И ГОРНОЕ ДЕЈЮ

ISSN 2224-9923

Volume/ Toм 18 №1, 2018

http://vestnik.pstu.ru/geo/

УДК 622.276:551.584

Article / Статья

(C) PNRPU / ПНИПУ, 2018

\title{
THE EXPERIMENTAL STUDY OF MICROCLIMATIC CONDITIONS AND FACTORS OF THEIR FORMATION IN THE OIL MINE
}

\author{
Yuri A. Klyukin, Mikhail A. Semin, Artem V. Zaitsev
}

Mining Institute of the Ural Branch of the Russian Academy of Sciences (78 Sibirskaya st., Building A, Perm, 614007, Russian Federation)

\section{ЭКСПЕРИМЕНТАЛЬНОЕ ИССЛЕДОВАНИЕ МИКРОКЛИМАТИЧЕСКИХ УСЛОВИЙ И ФАКТОРОВ ИХ ФОРМИРОВАНИЯ В НЕФТЯНОЙ ШАХТЕ}

\section{Ю.А. Клюкин, М.А. Семин, А.В. Зайцев}

Горный институт Уральского отделения Российской академии наук (614007, Россия, г. Пермь, ул. Сибирская, 78a)

Received / Получена: 27.07.2018. Аccepted / Принята: 03.09.2018. Published / Опубликована: 28.09.2018

Key words:

microclimatic conditions, oil mine, thermal mining oil recovery, ventilation of mines, experimental survey, temperature and humidity survey, slope block, heat exchange, rock mass, drilling gallery, oil production, high viscosity oil, temperature, relative humidity, classification.

\begin{abstract}
Patterns of formation of the thermal regime of the mine workings in oil mines are experimentaly studied. Results are described on example of oil mine No. 1 of the Oil Mine Control Unit Yareganeft of LUKOIL-Komi LLC. In the example given the thermal regime of mine workings is largely determined by the unique technology of oil extraction by the thermal mining method used in the Yaregskoye field of high-viscosity oil and involving the injection of superheated water vapor into the reservoir. That leads to subsequent heating of an oil reservoir and oil contained. Measurements of microclimatic parameters in mine workings (temperature, relative humidity, air velocity) were used to develop a computer model of the mine ventilation network in the AeroSet analytical complex and further analysis of the distribution of microclimatic parameters on this model. During the experimental survey the effectiveness of various mining engineering measures currently used at the oil mine and reducing the influence of the heavy thermal regime in the workings of oil mines was also investigated. The research conducted allowed to identify factors that form microclimatic conditions in various mine workings such as in the main air supply and ventilation workings, in the opening and development workings, and also in the process chambers. The most significant processes that caused nonstationarity of the thermal regime of the mine workings of the oil mine are described. Classification of these factors was carried out depending on the direction of their thermal effect, on the location of the source and on the final mechanism of heat transfer. Classification in terms of the microclimatic parameters of air in oil mine No. 1 presented in graphics is the main result of the work. This classification is the basis for the development of mathematical models of unsteady heat and mass transfer processes occurring in oil mines.
\end{abstract}

Описаны результаты экспериментального исследования закономерностей формирования теплового режима горных выработок нефтяных шахт на примере нефтяной шахты № 1 НШУ «Яреганефть» ООО «ЛУКОЙЛ-Коми». В данном случае тепловой режим горных выработок во многом определяется уникальной технологией извлечения нефти термошахтным способом, применяемой на Ярегском месторождении высоковязкой нефти и подразумевающей закачку в пласт перегретого водяного пара, приводящую к последующему нагреву нефтяного пласта и содержащейся в нем нефти. Проведенные измерения микроклиматических параметров в выработках шахты (температуры, относительной влажности, скорости воздуха) использованы для разработки компьютерной модели вентиляционной сети шахты в аналитическом комплексе «АэроСеть» и дальнейшего анализа распределения микроклиматических параметров на данной модели. В ходе экспериментальной съемки также исследована эффективность различных горнотехнических мероприятий, применяемых в настоящее время на нефтяной шахте и позволяющих снизить влияние тяжелого теплового режима в выработках нефтяных шахт. Проведенные исследования позволили выявить факторы, формирующие микроклиматические условия в различных горных выработках шахты: в главных воздухоподающих и вентиляционных выработках, во вскрывающих и подготовительных выработках, а также в технологических камерах. Описаны наиболее существенные процессы, являющиеся причиной нестационарности теплового режима горных выработок нефтяной шахты. Проведена классификация данных факторов в зависимости от направленности их теплового воздействия, от местонахождения источника и от конечного механизма теплоотдачи. Основным итогом работы является представленная в графическом виде классификация факторов изменения микроклиматических параметров воздуха в нефтяной шахте № 1. Данная классификация является основой для разработки математических моделей нестационарных тепломассообменных процессов, протекающих в нефтяных шахтах.

Yuri A. Klyukin (Author ID in Scopus: 57188969203) - Leading Engineer (tel.: +007 34221654 92, e-mail: aeroyuri@gmail.com).

Mikhail A. Semin (Author ID in Scopus: 56462570900) - PhD in Engineering, Research Fellow (tel.: +007 342 216 54 92, e-mail: mishkasemin@gmail.com). The contact person for correspondence.

Artem V. Zaitsev (Author ID in Scopus: 56734117000) - PhD in Engineering, Head of the Sector (tel.: +007 342 216 54 92, e-mail: aerolog.artem@gmail.com).

Клюкин Юрий Андреевич - ведущий инженер (тел.: +007 34221654 92, e-mail: aeroyuri@gmail.com).

Семин Михаил Александрович - кандидат технических наук, научный сотрудник (тел.: +007 3422165492 , e-mail: mishkasemin@gmail.com). Контактное лицо для переписки.

Зайцев Артем Вячеславович - кандидат технических наук, заведующий сектором (тел.: +007 34221654 92, e-mail: aerolog.artem@gmail.com). 


\section{Introduction}

Providing the amount of air necessary to maintain an explosion-proof and breathable atmosphere in underground mines is traditionally one of the main tasks of the ventilation systems of shafts and mines [1, 2]. Nowadays, the share of highly efficient equipment and technologies hardto-access mining reserves increases. Therefore, in order to provide miners with safe working conditions that affect competitive production costs and labor productivity, it is extremely important to ensure favorable microclimat in underground mining operations [3-5]. Under these conditions, ventilation systems of shafts have to provide air conditioning that serve to ensure and maintain comfortable and safe microclimatic conditions in the underground work areas [3, 6-9].

The problem of ensuring safe microclimatic working conditions is relevant in relation to the oil mines of the Yaregskoye high-viscosity oil field developed using the thermo-mine method [10-12]. Thermal method of extraction of high-viscosity oil involves the injection of coolant (superheated water vapor) into the oil reservoir through vertical or inclined injection wells. Due to the filtration of the fluid injected into the reservoir, the oil reservoir gradually warms up. When the oil contained in the reservoir warms up, its viscosity drops by several orders of magnitude, as a result of which oil flows under the influence of gravity into inclined production wells drilled from the shafts of the oil reservoir gallery (see Fig. 1).

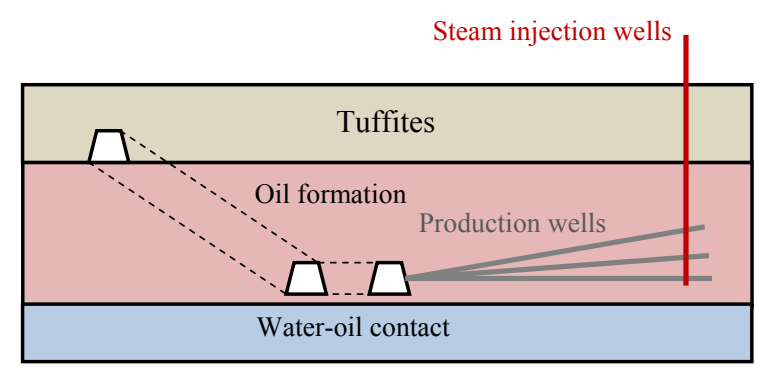

Fig. 1. Schematic diagram of the location of wells and shafts of the slope block of an oil mine in an underground-surface scheme of oil reservoir development using a thermo-shaft method, vertical section

The high temperature of steam injected into the reservoir (more than $+100{ }^{\circ} \mathrm{C}$ ) leads to a significant increase in the initial temperature of the rock mass (reservoir) and oil contained in it. This, in turn, leads to a deterioration of the microclimatic parameters in the atmosphere of mine shafts, exceeding the maximum allowable air temperature in mines according to "Safety rules..." $[13,14]$. At the same time, the thermal regime of mine shafts is one of the production factors and should, first of all, ensure labor safety, eliminate the occurrence of accidents, occupational diseases, and help preserve the health of workers [15].

Therefore, the topic is relevant and devoted to the experimental study of the laws governing the formation of the thermal regime of the mine workings of oil mines on the example of oil mine No. 1 of OMCU Yareganeft LUKOIL-Komi LLC.

\section{Mine ventilation overview}

Oil formation of the oil mine No. 1 of the OMCU Yareganeft contains three shafts such as lifting shaft, ventilation shaft, and ventilation shaft No. 2. Aeration of oil mines of the shaft No. 1 OMCU Yareganeft is performed by the exhaust system of central circuit [16]. Lifting and ventilating shafts are designed to supply fresh air to underground mine workings and are equipped with air heaters. Ventilation shaft number 2 is used for the issuance of exhaust air from the mine. The shaft is connected to the air way, where the main fan VCD-31.5 is installed.

The main air path through the oil shaft can be described by the following sequence of mine workings:

- lifting shaft and ventilation shaft No. 1;

- main air supply mine workings of tuffit formation;

- man way;

- production (drilling) gallery;

- slope;

- main airways of the tuffit formation;

- ventilation shaft No.2.

The Fig. 2 shows a computer model of an oil ventilation network of the oil mine No. 1, built in AeroSet analytical software [17]. Tuffit mine workings are highlighted yellow; the blue color indicates the production of slope blocks, green and gray ones indicate the vertical workings (shafts, wells).

\section{Experimental survey results}

The subject of research during the experimental survey was the micro-climatic parameters of air in the mine workings of various types: the main air supply and ventilation; revealing and preparatory, 
as well as technological chambers. Measured Parameters are as follows:

1) air temperature (thermal moisture tester Fluke-971),

2) relative humidity (thermal moisture tester Fluke-971),

3) average velocity of the air jet over the section (anemometer APR-2),

4) cross section of mine workings (laser rangefinder Leica Disto D2),

5) surface temperature of mine workings and other sources of heat transfer (Flir SC660 thermal imager).

Temperature-humidity and air-depressive surveys were conducted by the Mining Institute of the Ural Branch of the Russian Academy of Sciences with the participation of the authors. The Fig. 3 presents the generalized results of temperature and humidity surveys conducted in 2017. Gradient painting shows temperature distribution throughout the mine ventilation network. Blue color corresponds to air temperatures of $+26{ }^{\circ} \mathrm{C}$ and lower. The Fig. 3 also shows the intensity of heat release on individual sloping blocks of the mine (highlighted with a dotted line).

Heat and mass transfer processes occurring when air moves through the air ways of oil shafts do not have pronounced specificity associated with the development system used. It is characterized by insignificant heating due to hydrostatic compression $\left(1-2{ }^{\circ} \mathrm{C}\right)$ and heat exchange with the rock mass having temperature at that depths of about +5 to $+10{ }^{\circ} \mathrm{C}$.

The main air ways of the tuffit formation are characterized by a smooth change in air temperature along the path from the air ways to the inclined blocks. At the same time, the cold period of the year is characterized by heating the air from a temperature of $2-5$ to $18-20{ }^{\circ} \mathrm{C}$, depending on the distance of the slope block from the air way or wells. In the warm period of the year, both heating and cooling of the air can occur depending on the temperature of the atmospheric air.

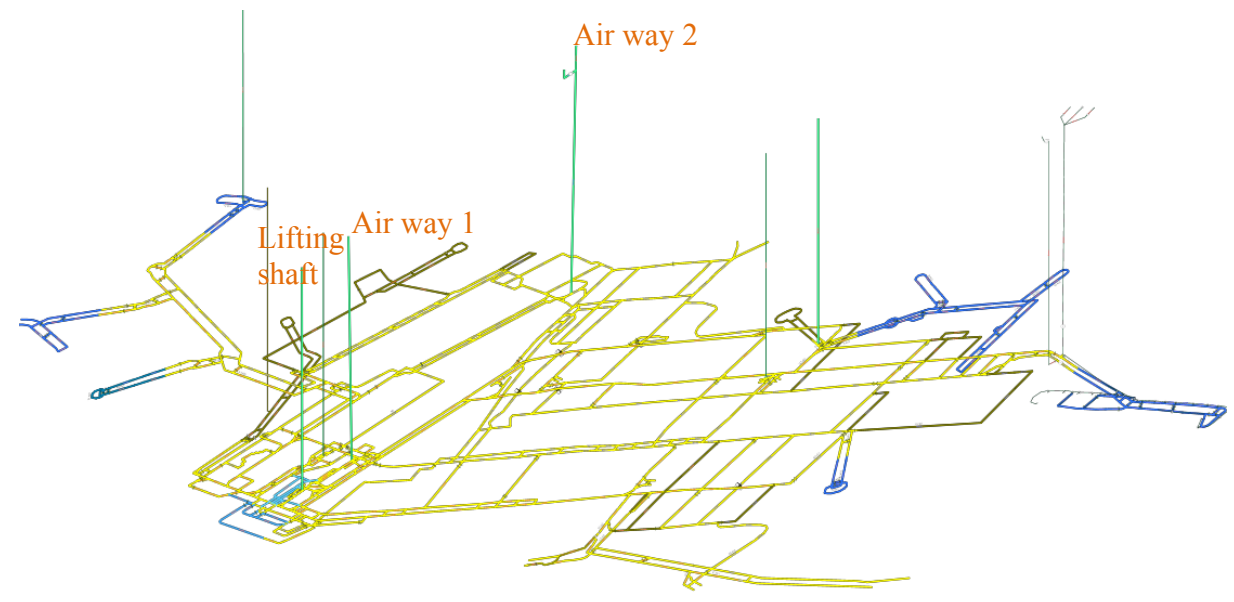

Fig. 2. Oil mine ventilation network No. 1

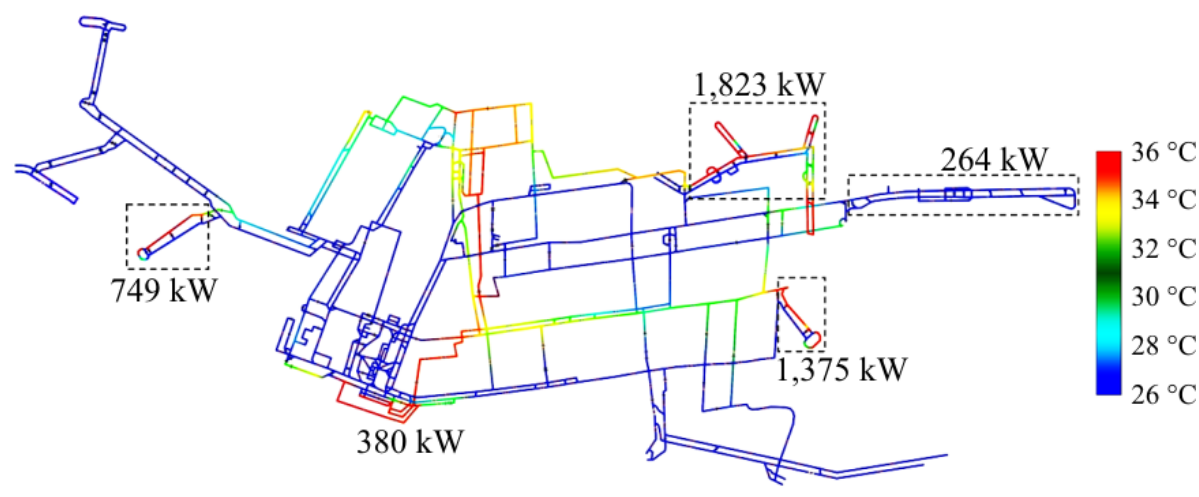

Fig. 3. Distribution of air temperature in the ventilation network of the oil shaft No. 1, temperature and humidity survey 

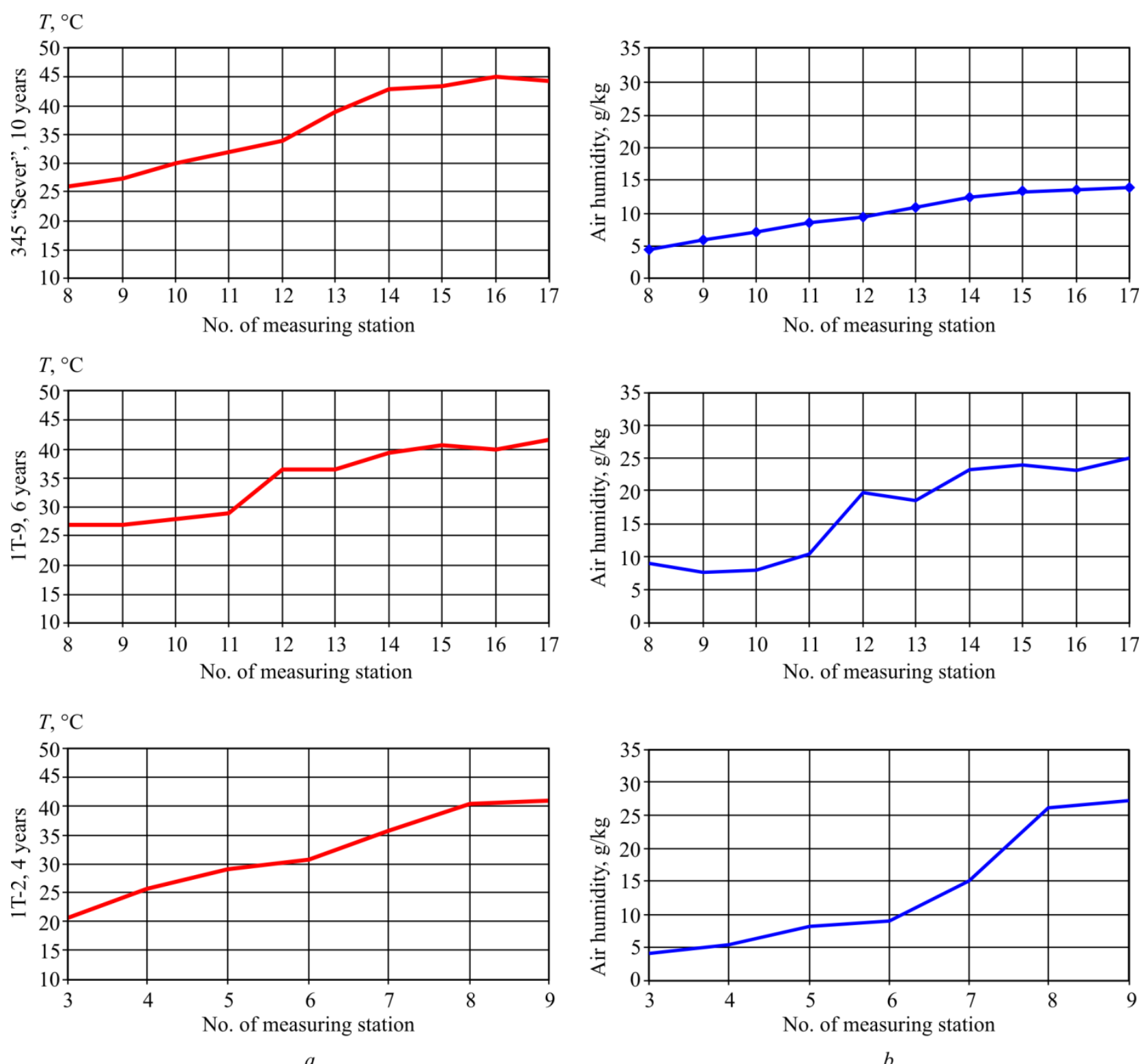

Fig. 4. Distribution of temperature (a) and air humidity, $\mathrm{g} / \mathrm{kg}(b)$ along the length of the drilling galleries of sloping oil mine blocks

There is no significant moistening of the air flow in the main air supply workings observed. There are local sources of moisture supply in the form of steam breakthroughs in crack systems, which influence the microclimatic conditions of the main air supply openings (a limited time until their liquidation by mining means).

The moisture content of the air entering the slope unit is generally determined by the initial moisture content of the atmospheric air. There is a smooth but more intense heating of the air in the climb of the slope block, as well as in the main air ways, which is also accompanied by more substantial moisture gains.
There are processes similar to the ratio of heat and moisture inputs observed in all existing slope blocks. Slope block 3T-9 is exception. The heat exchange there has a fundamentally different character - air cooling is observed with moisture condensation. This is explained by the fact that this section is at the initial stage of mining, when the temperature of the rocks is close to the natural temperature at a given depth, i.e. $5-7^{\circ} \mathrm{C}$.

Processes of heat and moisture supply are significantly intensified and usually reach maximum values for the mine as a whole in the production gallery of the slope block, where oil is being produced. In terms of microclimatic conditions, this process is further enhanced by the 
fact that the production gallery is characterized by the minimum air flow rate for the corresponding path. Thus, the minimum air flow accounts for the maximum heat flow, which leads to a sharp increase in air temperature as well as contact with the oily liquid, which contributes to a sharp air humidification.

The Fig. 4 shows graphs of temperature and moisture content of the air as it moves through the production galleries of sloping blocks 345 "Sever", 1T-2 and 1T-9 of oil mine No. 1. It is also indicated during how many years presented slope blocks were into production.

In all the cases air heating is accompanied by its substantial humidification; these values correlate quite well.

When the outgoing air stream moves from the production gallery along the slope of the slope unit, it mixes with less heated air streams coming from the pumping chamber and through the ventilating facilities of the inclined part of the slope. Air usually cools due to heat exchange with the rock during the movement along a slope. Moisture in the slope is weak. In some cases, there is an additional heating emanating from the slope of the air stream.

Air also cools in the main air ways of the oil mine due to leaks through the ventilation structures and service chambers. There is a heat exchange with the rock mass. Due to these processes the temperature of the air flow decreases along the path to the air way No. 2.

Microclimatic conditions of sloping blocks change significantly while mining the reserves of the corresponding section of the shaft field. The change occurs from the cooling of microclimate during the period of excavation of mine workings and start of production to the heating during the period of working out and preservation of the slope block. This period usually takes from 10 to 15 years, depending on the mining and geological conditions of the site being produced and adopted parameters of the development system.

\section{Field observations of applied mining engineering measures}

Various measures to reduce the impact of heavy thermal conditions in the workings of oil mines are being tested with the introduction of the thermal mining recovery method. The most effective ones are currently used.
Under the conditions of oil mines, irrigation systems ("foggers") were implimented using water from the central water supply system with discharging water through mine drainage (open circuit). Water enters this system from a reservoir with a temperature of about $5-7{ }^{\circ} \mathrm{C}$ and is sprayed through nozzles into the mine atmosphere. These systems are usually applied directly in the drilling galaries of the slope blocks. Air is moistened and cooled during the heat and mass exchange of air with chilled water.

The irrigation systems used in the oil shafts represent a system of two pipelines located 5-7 meters apart from each other with a spray nozzle at the end (see thermal photograph in Fig. 5).

The efficiency of the existing irrigation system can be characterized by a decrease in air temperature with initial parameters of $40{ }^{\circ} \mathrm{C}$ at the relative humidity of $30 \%$ in the amount of $10 \mathrm{~m}^{3} / \mathrm{s}$ to $37.8{ }^{\circ} \mathrm{C}$ with the relative humidity of $38 \%$.

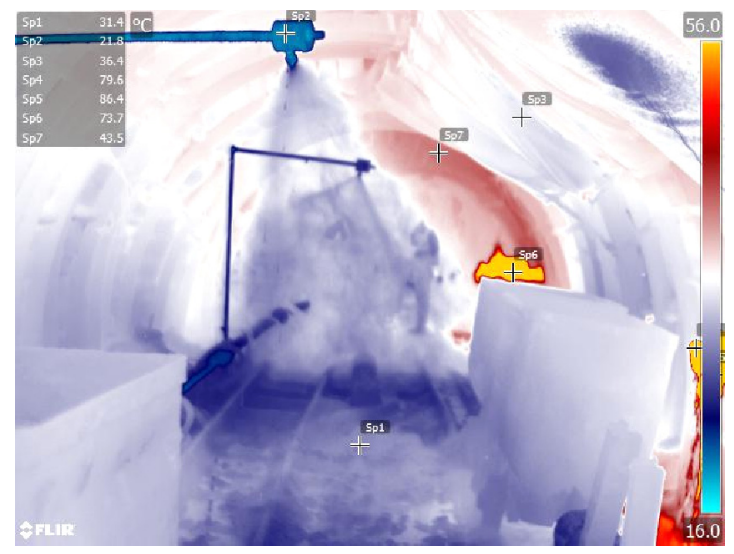

Fig. 5. Thermal image of the irrigation system installed in the operating gallery

The action is aimed at additional protection of miners from splashing of the heated oil-containing liquid when purging production wells. In addition, these shelters reduce the intensity of air mixing in the volume of the production gallery.

The action is aimed at eliminating the drip of heated oily liquid from the roof of the mine. In addition, these shelters reduce the intensity of heat exchange of air with the surface of the mine and the array in the area of the roof.

In the production gallery, the tightening of the mountain lining, in addition to the enclosing, also has a heat-insulating function. Timely monitoring of the condition and repair of the inhaling reduce the intensity of heat exchange between the air and the heated rock mass. 


\section{Study of factors that set a thermal regime in oil shafts}

Existing factors that set microclimatic parameters in the mine workings of oil shafts can be classified into three groups depending on the direction of their heat exposure:

1) air heating,

2) decrease in air temperature,

3) alternating action.

Factors of each group are analized in the next section.

\section{Air heating factors}

Mine air is heated for one of the following reasons: transfer of the heat of steam injected into the reservoir, hydrostatic air compression, heat transfer from mining equipment, heat emission from viscous heating of the air flow caused by internal friction.

Air warming up due to the heat of steam injected into the reservoir. Transfer of heat from the warmed up steam injected into the reservoir through the wells from the surface is carried out by various mechanisms:

- Diffusion thermal conductivity in the oil reservoir and adjacent layers of the rock mass.

- Convective heat transfer in the massif together with the oil-containing fluid flowing inside the formation.

- Heat transfer through the production wall.

- Heat transfer from oil transported through the mine workings system from oil wells to the surface.

- Mass exchange heat transfer due to steam outflow from large reservoir cracks to the mine atmosphere.

It is advisable to classify the factors for heating the mine air depending on the location of the source and the final mechanism of heat transfer:

1. Heat transfer at the interphase "massif - air":

- Heat transfer from the heated surfaces of mine workings of sloping blocks (oil reservoir).

- Transfer of heat from the heated surfaces of the mine workings of the main air supplying and ventilation ways (tuffite formation).

2. Heat transfer through the liquid-air interface:

- Heat transfer from an oily liquid to air through the metal wall of the pipeline.

- Heat dissipation from the transported oilcontaining liquid in the production gallery.
- Heat dissipation from oil outlets from the walls of workings.

3. Heat transfer due to convective mass transfer when steam enters the mine atmosphere and mixes it with air:

- Steam entry into the mine atmosphere during oil production in the production gallery.

- Steam entering the mine atmosphere during the transportation of oily liquid in an open way.

- Steam entering the mine atmosphere through a system of cracks in the massif.

4. Other sources of heat gain.

- Heat from mining equipment.

- Viscous air heating.

The physical mechanism of the factors responsible for heat transfer at the mass-air interface can be described as follows. The rock mass has the property of absorbing or releasing heat into the space of mine workings, filled with air, depending on the temperature ratio of the rock mass, walls of mine workings and air. Ha Rock media absorb heat of the air of a temperature above $+30{ }^{\circ} \mathrm{C}$ that moves through the air ways of oil mines of the OMCU Yareganeft. The higher the average air velocity in the mine and greater the area of air contact with the rock media or lining the more intensive heat exchange of the mine air with the rock media. That heat exchange is convective and is determined by the parameters of flow turbulence in a thin temperature boundary layer near the walls of mine workings (see Fig. 6) [3, 18-21].

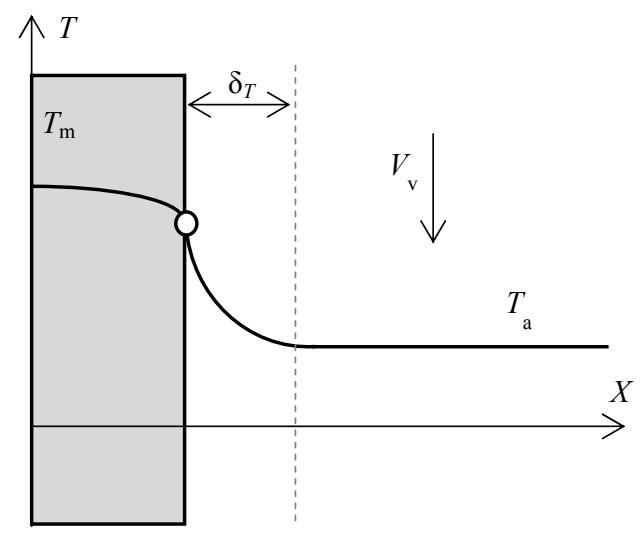

Fig. 6. Change in air temperature in the boundary layer

Air at the border with the mining output has a temperature equal to the temperature of the massif (or lining) $T_{\mathrm{m}}$. There is a convective vortex mixing of the flow in the temperature boundary layer of small thickness $\delta T$. In this layer, the air 
temperature varies from the temperature of the mine working wall to the temperature $T_{\mathrm{v}}$ in the flow core. The intensity of heat exchange of mine air with the rock mass is determined by the intensity of the vortex turbulent movement of air in the boundary layer and is described by the empirical linear Newton-Richmann law [19, 22]

$$
q=\alpha\left(T_{\mathrm{v}}-T_{\mathrm{m}}\right),
$$

where $\alpha-$ heat transfer coefficient, integrally taking into account the intensity of vortex mixing of air flows in the boundary layer, $\mathrm{W} /\left(\mathrm{m}^{2} \cdot{ }^{\circ} \mathrm{C}\right)$.

Heat transfer between the oil liquid and air through the pipe wall is determined by following parameters: thermal resistance of the thermal insulation of the pipe wall, thermal resistance of the boundary fluid layers at the boundaries "metal wall-oil" and "metal wall-air".

The heat transfer law at the "metal wall-oil" boundary is characterized by the following Nusselt number for convective fluid flow in pipes [23-25]:

$$
\mathrm{Nu}=0,021 \operatorname{Re}_{\mathrm{o}}^{0.8} \operatorname{Pr}_{\mathrm{o}}^{0.43}\left(\frac{\operatorname{Pr}_{\mathrm{o}}}{\operatorname{Pr}_{\text {wall }}}\right)^{0.25} \varepsilon_{l},
$$

where $\mathrm{Re}_{\mathrm{o}}-$ Reynolds number for flow of oil liquid; $\operatorname{Pr}_{0}$ - turbulent Prandtl number for an oil liquid in the flow core; $\operatorname{Pr}_{\text {wall }}$ - turbulent Prandtl number for an oil liquid the pipeline wall, $\varepsilon_{l} \approx 1-$ coefficient taking into account the change in the average coefficient of heat transfer along the length.

Heat transfer at the "metal wall-air" boundary is characterized by the following Nusselt number [26]:

$$
\mathrm{Nu}=0.018 \operatorname{Re}_{\mathrm{a}}^{0.8},
$$

where $\mathrm{Re}_{\mathrm{a}}-$ Reynolds number for air flow.

Heat dissipation from the transported oilcontaining liquid in the producction gallery. Primary transportation of oily liquid from production wells to the sump of the inclined block is carried out by the open method along the groove, and sometimes across the soil of the production gallery or the workings of the manway and slope. The movement of oil liquid occurs by gravity due to the design slope of the workings of the production gallery. During the flow of oil liquid through the operating gallery, air is heated by forced convection and evaporation of water vapor contained in the produced oil. The magnitude of heat generation is determined by the initial temperature and flow rate of the flowing fluid, heat exchange surface area, velocity and pattern of motion of liquid media, and heat exchange time.

Heat dissipation from oil outlets from the walls of workings. The mine workings of the production galleries of the oil mines are passed through the oil reservoir. As a result, the gravitational runoff of heated oil occurs both in production wells and directly to the walls of the mine workings of the production gallery. As a result, a liquid film is formed on the walls of mine workings, intensifying heat exchange. The mechanism of heat transfer in this case can be described in the framework of the theory of heat transfer in liquid films [41].

Convective mass exchange of mine air and steam. Mine air and steam entering the mine atmosphere through pores and cracks in the massif or from oil producing wells are mixed according to the law of equal mass fractions, and the temperature $T_{\text {mix }}$ of the steam-air flow formed as a result of mixing two streams with different temperatures $T_{\mathrm{a}}$ and $T_{\mathrm{s}}$, is determined by the formula [27]

$$
T_{\text {mix }}=\frac{G_{\mathrm{a}} T_{\mathrm{a}}+G_{\mathrm{s}} T_{\mathrm{s}}}{G_{\mathrm{a}}+G_{\mathrm{s}}},
$$

where $G_{\mathrm{a}}$ and $G_{\mathrm{s}}$ - mass flow rate of air and steam, respectively, $\mathrm{kg} / \mathrm{s}$.

Heat release from mining equipment. Mining equipment with diesel and electric drives emits thermal energy into the mine atmosphere. For engineering calculations of heat generation, process equipment can be considered as absolute sources of heat. The heat generation power $W$ by the known useful power of the machine $N$ and the efficiency $\eta$ can be determined as follows $[22,28]$ :

$$
W=\frac{1-\eta}{\eta} N .
$$

The increase in air temperature $\left({ }^{\circ} \mathrm{C}\right)$, depending on heat generation at a known density, heat capacity and air flow, is determined by the following formula [22, 29]:

$$
\Delta T=\frac{W}{\rho c Q},
$$

where $\rho-$ density of air blowing on the machine, $\mathrm{kg} / \mathrm{m}^{3} ; c$ - heat capacity of the air 
blowing in the machine, $\mathrm{kJ} / \mathrm{kg} ; \quad Q_{-}$air consumption in mining with a machine, $\mathrm{m}^{3} / \mathrm{s}$.

Viscous air heating. The increment of heat flow due to viscous heating is calculated as work per unit time spent on overcoming aerodynamic resistance and movement of air [30-31]:

$$
W_{\mathrm{v} . \mathrm{h}}=H Q \text {, }
$$

where $H$ - pressure drop in the considered system of mine workings (in this case throughout the mine ventilation network) caused by air friction when overcoming aerodynamic drag, $\mathrm{Pa} ; Q$ - total air consumption in the considered system of mine workings, $\mathrm{m}^{3} / \mathrm{s}$.

The increment in air temperature $\left({ }^{\circ} \mathrm{C}\right)$ depending on the increment of heat $W_{\text {v.h }}$ with a known heat capacity and air flow is determined by a formula similar to (2).

\section{Air temperature reduction factors}

Exhaust mine air emanating from sloping blocks of oil mines, has a temperature above $30{ }^{\circ} \mathrm{C}$. On the way from the slope blocks to the air way, the air is cooled due to the following factors:

1. Leaks through ventilation.

2. Heat transfer of the outgoing jet with the rock mass.

There is a decrease in the temperature of the outgoing air stream along the path to the ventilation shaft due to air leaks and subsequent mixing with air streams emanating from sloping blocks.

Mixing of cold and heated air jets occurs according to the law of equal mass fractions, and the temperature $T_{\text {mix }}$ airflow resulting from mixing two streams with different temperatures $T_{1}$ and $T_{2}$, determined by a formula similar to (1):

$$
T_{\text {mix }}=\frac{G_{1} T_{1}+G_{2} T_{2}}{G_{1}+G_{2}},
$$

where $G_{1}$ and $G_{2}$ - mass flow rates of two air flows, $\mathrm{kg} / \mathrm{s}$.

The physics of the factors responsible for the heat exchange of the outgoing air with the rock mass is described above.

\section{Multidirectional factors and factors of variable action}

For the conditions of the oil mine No.1 of OMCU Yareganeft we can distinguish the following thermal factors of variable action:
1. Seasonal variations in atmospheric air parameters.

2. Hydrostatic cooling and air heating.

Seasonal fluctuations of the initial parameters of the air entering the mine determine the different nature and rate of changes in temperature and humidity of the air flow in the network of mine workings during different periods of the year. [32, 33 ]. In the cold period of the year, air enters the air ways at a temperature close to its lower maximum allowable "Safety Rules..." threshold $+2{ }^{\circ} \mathrm{C}$. Atmosphere air is heated using air preparation systems. When cold air moves along the air supply trunk, the workings of the near-barrel yard and the main air supply paths, it is heated due to heat exchange with rocks having a higher temperature due to the natural geothermal distribution of the temperature of the massif, technogenic heating of the formation and heat accumulated by the contour part of the rock mass in the warm period of the year.

During the warm period of the year, the temperature of the air entering the air ways can reach $35{ }^{\circ} \mathrm{C}$ (absolutely maximum air temperature for the city of Ukhta [34]). During this period, there is a reverse tendency such as air cooling in the areas of the air-supply trunk, near-barrel yard and main air supply paths due to lower temperature of rocks (taking into account anthropogenic impact on the formation), persistent long-term cooling of the marginal part of the rock mass in the cold season.

In working areas on sloping blocks located at a distance of more than $1 \mathrm{~km}$ from the near shaft, the temperature of the mine air usually reaches its established average annual value due to heat exchange with the rock mass throughout the entire path of the air stream from the surface to the working zone [22, 35-37]. Thus, this factor does not have a significant effect on the microclimatic parameters of the working zones of sloping blocks.

When calculating heat exchange processes in vertical and inclined mine workings, it is necessary to take into account the presence of hydrostatic heating/cooling of air during movement in the field of gravity and the influence of this process on the formation of the temperature field and geothermal gradient of the natural temperature field of rocks. In the conditions of oil mines with a depth of about $200 \mathrm{~m}$, the influence of this factor leads to a change in air temperature within $2{ }^{\circ} \mathrm{C}$ [38-39]. 


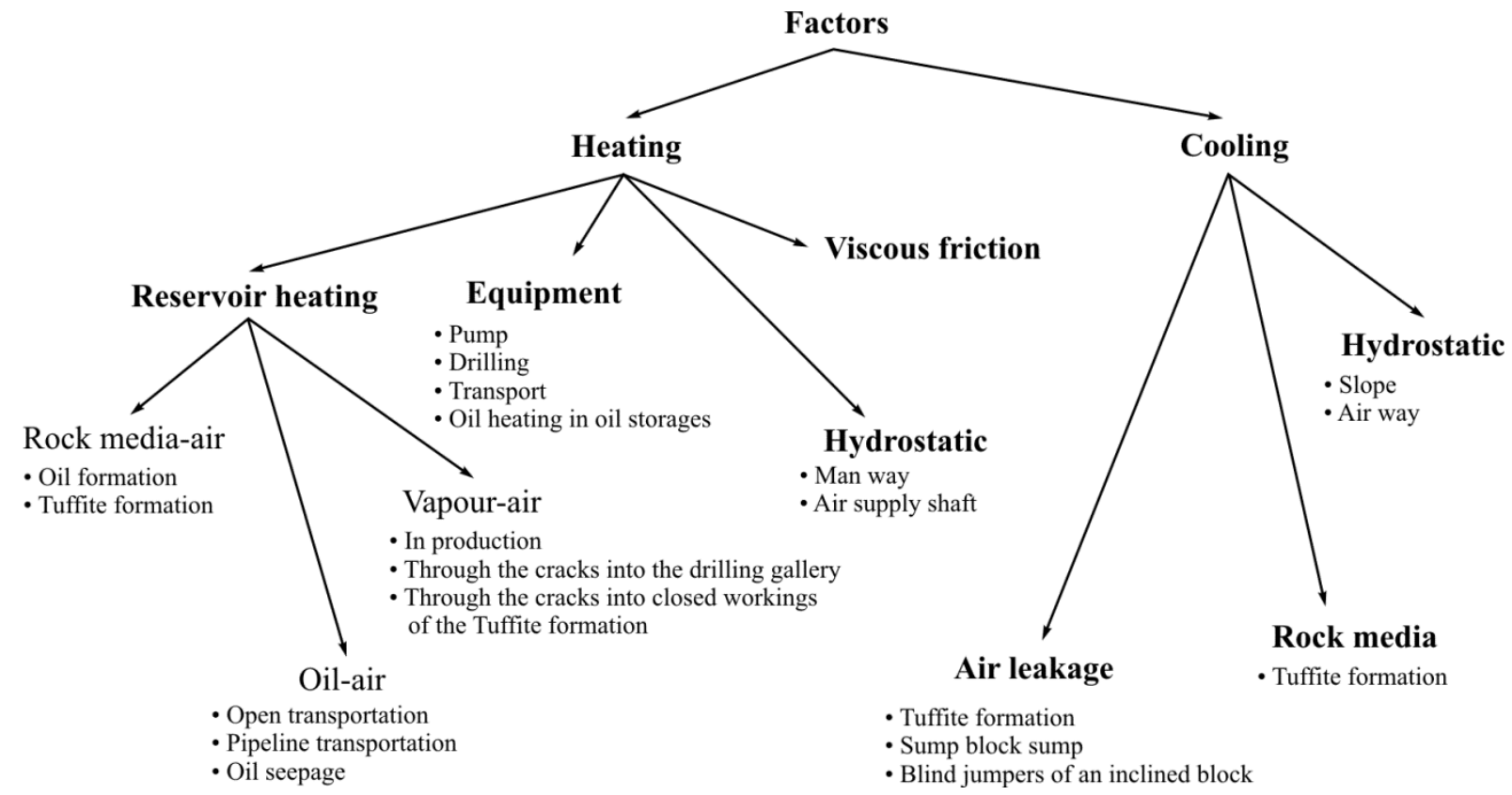

Fig. 7. Classification of microclimate formation factors in the oil mine

The dependence of the increase in air temperature due to hydrostatic compression from the depth of the shaft $L$ is determined from the following formula [40]:

$$
\Delta T=\frac{g L}{c+R / M},
$$

where $g-$ gravitational acceleration, $\mathrm{m} / \mathrm{s}^{2}$; $c$ - specific mass heat capacity of air at constant volume, $\mathrm{J} / \mathrm{kg} / \mathrm{K} ; R$ - universal gas constant, $\mathrm{j} / \mathrm{mol} / \mathrm{K} ; M$ - molar mass of air, $\mathrm{kg} / \mathrm{mol}$.

In addition to cooling the heated air stream emanating from the slope block, heat exchange has a seasonal variable effect on the temperature of the air entering the mine. In a given constant mode of air distribution at the entrance to remote inclined blocks, a quasi-stationary heat balance is established when the air temperature in the workings is almost equal to the temperature of the walls of the rock mass.

A general classification of the factors described above, leading to a change in microclimatic parameters in oil mines, is presented in Fig. 7 as a diagram.

As a result of field studies, the parameters of heat and mass transfer processes and the range of values of physical quantities characteristic of the conditions of oil mines were determined. The most significant processes that require consideration in the development of a mathematical model of heat transfer are identified:
- heat exchange with a solid heated surface (massif, lining, well bindings, pipelines);

- heat exchange with the surface of the heated oily liquid;

- steam flow into the mine atmosphere (from an oily liquid, through breakthroughs through wells and cracks);

- flow oil and steam in an media;

- non-stationary heating of the media.

The range of input parameters for the development of a mathematical model is presented in the table.

\section{Table}

Range of parameters of the drilling gallery for various slope blocks of oil mine No. 1

\begin{tabular}{|l|c|c|}
\hline \multirow{2}{*}{\multicolumn{1}{|c|}{ Parameter }} & \multicolumn{2}{c|}{ Value } \\
\cline { 2 - 3 } & minimal & maximum \\
\hline Section of workings, $\mathrm{m}^{2}$ & 7 & 12.8 \\
\hline Tightening thickness, $\mathrm{m}$ & 0.05 & 0.05 \\
\hline Heat conductivity of a tightening, $\mathrm{W} / \mathrm{m} /{ }^{\circ} \mathrm{C}$ & 0.15 & 0.4 \\
\hline Pressure of bursting steam, bar & 1 & 1.2 \\
\hline Steam breakthrough temperature, ${ }^{\circ} \mathrm{C}$ & 100 & 120 \\
\hline Temperature of the oil liquid, ${ }^{\circ} \mathrm{C}$ & 6 & 110 \\
\hline Diameter of well pipelines, $\mathrm{m}$ & 0.05 & 0.25 \\
\hline Length of production gallery, $\mathrm{m}$ & 100 & 1000 \\
\hline Length of production wells, $\mathrm{m}$ & 100 & 800 \\
\hline Distance to steam wells, $\mathrm{m}$ & 50 & 800 \\
\hline
\end{tabular}

\section{Conclusion}

The paper presents the results of the experimental study of the patterns of formation of the thermal regime of the mine workings of oil 
mines on the example of oil mine No. 1 of the OMCU Yareganft LUKOIL-Komi LLC The studies were carried out by the Mining Institute of the Ural Branch of the Russian Academy of Sciences with the participation of the authors of the article from 2011 to 2018 . The main results of the experimental study are:

- graphically presented classification of factors for changing the micro-climatic parameters of air in an oil mine (see Fig. 7),

- values of the microclimatic parameters of the mine air and the power of heat release in various mine workings (see Fig. 3-5, Table).

Resulting classification and measured air parameters are the basis for the development of mathematical models of unsteady heat and mass transfer processes occurring in oil mines.

The study was carried out with the financial support of the Council on grants of the President of the Russian Federation in the framework of the research project No. MK-6244.2018.5.

\section{References}

1. Skochinskiy A.A., Komarov V.B. Rudnichnaya ventilyatsiya [Mine ventilation]. Moscow, Ugletekhizdat, $1951,632 \mathrm{p}$.

2. Ushakov K.Z., Burchakov A.S., Puchkov L.A., Medvedev I.I. Aerologiya gornykh predpriyatiy [Aerology of mining enterprises]. Moscow, Nedra, 1987, 422 p.

3. McPherson M.J. Subsurface ventilation and environmental engineering. Chapman \& Hall, 2009, 824 p.

4. Zaytsev A.V., Levin L.Yu., Kazakov B.P., Klyukin Yu.A. Teplotekhnicheskie sistemy normalizatsii mikroklimaticheskikh parametrov vozdukha $\mathrm{v}$ glubokikh rudnikakh ZF PAO "GMK "Norilskiy nikel"" [Thermal systems for the normalization of microclimatic air parameters in the deep mines of the Polar Division of PJSC Norilsk Nickel GMK]. Mining Journal, 2018, no.6, pp.34-40.

5. Goncharov S.A., Dmitriev A.P. Termodinamicheskie protsessy $\mathrm{v}$ gornykh porodakh [Thermodynamic processes in rocks]. Moscow, Nedra, 1990, 360 p.

6. Dyadkin Yu.D., Shuvalov Yu.V., Timofeevskiy Yu.S. Gornaya teplofizika. regulirovanie teplovogo rezhima shakht i rudnikov [Mine thermal physics. Regulation of thermal conditions of mines and pits]. Leningrad, Leningradskiy gosudarstvennyy institut, 1976, $159 \mathrm{p}$.

7. Shcherban A.N., Kremnev O.A., Zhuravlenko V.Ya. Rukovodstvo po regulirovaniyu teplovogo rezhima shakht [Mine thermal regime management guide]. Moscow, Nedra, 1977, 359 p.

8. Wyndham C., Allan A., Bredell G., Andrew R. Assessing the heat stress and establishing the limits for work in a hot mine. Occupational and Environmental Medicine, 1967, vol.24, pp.255-271. DOI: 10.1136/oem.24.4.255

9. Howes M.J., Nixon C.A. Development of procedures for safe working in hot conditions. Proceedings of the $6^{\text {th }}$ International Mine Ventilation Congress. Society for Mining, Metallurgy, and Exploration, 1997.

10. Konoplev Yu.P. Nauchno-metodicheskie osnovy proektirovaniya $\mathrm{i}$ analiza termoshakhtnoy razrabotki neftyanykh mestorozhdeniy [Scientific and methodo- logical foundations of the design and analysis of thermomine development of oil fields]. Doctor's degree dissertation. Moscow, 2004, 253 p.

11. Levin L.Yu., Kormshchikov D.S. Osobennosti dobychi vysokovyazkoy nefti na primere Yaregskogo mestorozhdeniya [Features of high-viscosity oil production on the example of the Yaregskoye field]. Nauchnye issledovaniya $i$ innovatsii, 2010, vol.4, no.2, pp.33-36.

12. Ruzin L.M., Chuprov I.F., Morozyuk O.A., Durkin S.M. Tekhnologicheskie printsipy razrabotki zalezhey anomalno vyazkikh neftey i bitumov [Technological principles for development of deposits of abnormally viscous oils and bitumens]. Moscow, Izhevsk, Institut kompyuternykh issledovaniy, 2015, 480 p.

13. Tskhadaya N.D., Zhuykov A.E., Yagubov Z.Kh., Yagubov E.Z. Sozdanie bezopasnykh usloviy truda $\mathrm{v}$ neftyanykh shakhtakh pri teplovom vozdeystvii na plast [Creating a safe working conditions at thermal stimulation of formation]. Oil industry, 2013, no.9, pp.121-123.

14. Levin L.Yu., Semin M.A., Klyukin Yu.A. Otsenka effektivnosti sistemy raspredelennoy podachi okhlazhdennogo vozdukha kak sposoba upravleniya mikroklimaticheskimi parametrami shakht [Estimation of suballo-cated conditioned air distribution system efficiency as a method of mine microclimatic parameters control]. Gornyy informatsionno-analiticheskiy byulleten, 2013, no.12, pp.185-189.

15. Zaytsev A.V., Semin M.A., klyukin Yu.A. Issledovanie kriteriev normirovaniya mikroklimaticheskikh usloviy v gornykh vyrabotkakh [Improvement of microclimate conditions rationing criteria in mine airways]. Gornyy informatsionno-analiticheskiy byulleten (nauchnotekhnicheskiy zhurnal), 2015, no.12, pp.151-156.

16. Karataev A.F. Klassifikatsiya sposobov, skhem i sistem ventilyatsii shakht [Classification of methods, circuits and ventilation systems of mines]. Izvestiya tomskogo politekhnicheskogo universiteta. Inzhiniring georesursov, 1954, vol.79, pp.17-28. 
17. Kazakov B.P., Kruglov Yu.V., Isaevich A.G., Levin L.Yu. Razrabotka programmno-vychislitelnogo kompleksa "AeroSet" dlya rascheta ventilyatsionnykh setey shakht i rudnikov [Development of AeroSet software and computing complex for calculating the ventilation networks of mines and pits]. Gornyy informatsionnoanaliticheskiy byulleten (nauchno-tekhnicheskiy zhurnal), 2006, no.S3, pp.21-33.

18. Weyburne D. A mathematical description of the fluid boundary layer. Applied Mathematics and Computation, 2006, vol.175, pp.1675-1684.

19. Shlikhting G. Teoriya pogranichnogo sloya [Boundary layer theory]. Moscow, Nauka, 1974, 712 p.

20. Hall A.E. Computer techniques for calculating temperature increases in stopes and mine airways. Journal Mine Vent. Soc. of S. Africa, 1975, vol.28, no.4, pp.55-59.

21. Lambrechts J. Prediction of wet bulb temperature gradients in mine airways. Journal of the Southern African Institute of Mining and Metallurgy, 1968, vol.68, iss.8, pp.372-373.

22. Zaytsev A.V. Razrabotka sposobov normalizatsii mikroklimaticheskikh usloviy $\mathrm{v}$ gornykh vyrabotkakh glubokikh rudnikov [Development of methods for the normalization of microclimatic conditions in deep mines]. Ph. D. thesis. Perm, 2013, 168 p.

23. Dreytser G.A. Nestatsionarnyy konvektivnyy teploobmen pri turbulentnom techenii gazov i zhidkostey $\mathrm{v}$ kanalakh [Unsteady convective heat transfer in turbulent flow of gases and liquids in channels]. Teploenergetika, 1998, no.12, pp.29-38.

24. Arkle K. Use of thermal insulation materials in mines. Journal Mine Vent. Soc. of S. Africa, 1985, vol.38, no. 4 , pp.43-45.

25. Baker-Duly C. Design of a large flexible underground refrigeration installation. 4th Int. Mine Ventilation Congress. Brisbane, 1988, pp.443-449.

26. Levin L.Yu., Semin M.A., Zaytsev A.V. Razrabotka matematicheskikh metodov prognozirovaniya mikroklimaticheskikh usloviy $\mathrm{v}$ seti gornykh vyrabotok proizvolnoy topologii [Development of mathematical methods for predicting microclimatic conditions in the network of mine workings of arbitrary topology]. FTPRPI, 2014, no.2, pp.154-161.

27. Voss J. Control of the mine climate in deep coal mines. Proc. 1st Int. Mine Ventilation Congress. Johannesburg, 1975, p.331.

28. Levin L.Yu., Zaytsev A.V., Grishin E.L., Semin M.A. Raschet kolichestva vozdukha po soderzhaniyu kisloroda dlya provetrivaniya rabochikh zon pri primenenii mashin $\mathrm{s}$ dvigatelyami vnutrennego sgoraniya [The calculation of the amount of air on the oxygen content for ventilation of working areas when using machines with internal combustion engines]. Bezopasnost truda $v$ promyshlennosti, 2015, no.8, pp.43-46.
29. Voropaev A.F. Teoriya teploobmena rudnichnogo vozdukha i gornykh porod v glubokikh shakhtakh [Theory of heat exchange of mine air and rocks in deep mines]. Moscow, 1966, $252 \mathrm{p}$.

30. Semin M.A. Obosnovanie parametrov sistem ventilyatsii rudnikov $\mathrm{V}$ reversivnykh rezhimakh provetrivaniya [Substantiation of the parameters of the ventilation systems of mines in the reverse modes of ventilation]. Ph. D. thesis. Perm, 2016, 151 p.

31. Hooman K., Ejlali A. Effects of viscous heating, fluid property variation, velocity slip, and temperature jump on convection through parallel plate and circular microchannels. International Communications in Heat and Mass Transfer, 2010, vol.37, no.1, pp.34-38. DOI: 10.1016/j.icheatmasstransfer.2009.09.011

32. Shcherban A.N., Kremnev O.A. Nauchnye osnovy raschyeta i regulirovaniya teplovogo rezhima glubokikh shakht [Scientific basis for the calculation and regulation of the thermal regime in deep mines]. Kiev, Izdatelstvo AN USSR, 1959, vol.1, 430 p.

33. Levin L.Yu. Teoreticheskie i tekhnologicheskie osnovy resursosberegayushchikh sistem vozdukhopodgotovki shakht i rudnikov [Theoretical and technological bases of resource-saving air preparation systems for shafts and mines]. Doctor's degree dissertation. Perm, 2010, 274 p.

34. SP 131.13330.2012 Stroitelnaya klimatologiya. Aktualizirovannaya redaktsiya SNiP 23-01-99 [Construction climatology. Updated version of SNiP 23-01-99], 2012, 97 p.

35. Shalimov A.V. Teoreticheskie osnovy prognozirovaniya, profilaktiki $\mathrm{i}$ borby $\mathrm{s}$ avariynymi narusheniyami provetrivaniya rudnikov [Theoretical bases of forecasting, prevention and control of emergency violations of the ventilation of mines]. Doctor's degree dissertation. Perm, 2012, 329 p.

36. Gibson, K.L. The computer simulation of climatic conditions in mines. 15th APCOM Symp. Brisbane, 1977, pp.349-354.

37. McAdams W.H. Heat transmission. 3rd. ed. New York, McGraw-Hill, 1954, 478 p.

38. Kertikov V. Influence of relative variations along mine workings on air-flow temperature. Proceedings of the 7th International Mine Ventilation Congress. Poland: Research \& Development Center for Electrical Engineering and Automation, 2001, pp.85-90.

39. Kazakov B. P., Shalimov A. V., Semin M. A. Stability of natural ventilation mode after main fan stoppage. International Journal of Heat and Mass Transfer, 2015, vol.86, pp.288-293. DOI: 10.1016/j.ijheatmasstransfer.2015.03.004

40. Hartman H. et al. Mine ventilation and air conditioning. New York, John Wiley, 1997, 752 p.

41. Chhay M., Dutykh D., Gisclon M., Ruyer-Quil C. New asymptotic heat transfer model in thin liquid films. Applied Mathematical Modelling, 2017, vol.48, pp.844-859. 


\section{Библиографический список}

1. Скочинский А.А., Комаров В.Б. Рудничная вентиляция. - М.: Углетехиздат, 1951. - 632 с.

2. Аэрология горных предприятий / К.З. Ушаков, А.С. Бурчаков, Л.А. Пучков, И.И. Медведев. М.: Недра, 1987. - 422 с.

3. McPherson M.J. Subsurface ventilation and Environmental engineering. - Chapman \& Hall, 2009. - 824 p.

4. Зайцев А.В. Теплотехнические системы нормализации микроклиматических параметров воздуха в глубоких рудниках ЗФ ПАО «ГМК “Норильский никель”» / А.В. Зайцев, Л.Ю. Левин, Б.П. Казаков, Ю.А. Клюкин // Горный журнал. - 2018. - № 6. - С. $34-40$.

5. Гончаров С.А., Дмитриев А.П. Термодинамические процессы в горных породах. - М.: Недра, 1990. - 360 с.

6. Дядькин Ю.Д., Шувалов Ю.В., Тимофеевский Ю.С. Горная теплофизика. Регулирование теплового режима шахт и рудников. - Л.: ЛГИ, 1976. - 159 с.

7. Щербань А.Н., Кремнев О.А., Журавленко В.Я. Руководство по регулированию теплового режима шахт. Изд. 3-е, перераб. и доп. - М.: Недра, 1977. - 359 с.

8. Wyndham C., Allan A., Bredell G., Andrew R. Assessing the heat stress and establishing the limits for work in a hot mine // Occupational and Environmental Medicine. - 1967. - Vol. 24. - P. 255-271. DOI: $10.1136 /$ oem.24.4.255

9. Howes M.J., Nixon C.A. Development of procedures for safe working in hot conditions // Proceedings of the $6^{\text {th }}$ International Mine Ventilation Congress. Society for Mining, Metallurgy, and Exploration, 1997.

10. Коноплев Ю.П. Научно-методические основы проектирования и анализа термошахтной разработки нефтяных месторождений: дис. ... д-ра техн. наук. M., 2004. -253 c.

11. Левин Л.Ю., Кормщиков Д.С. Особенности добычи высоковязкой нефти на примере Ярегского месторождения // Научные исследования и инновации. 2010. - T. 4, № 2. - С. 33-36.

12. Технологические принципы разработки залежей аномально вязких нефтей и битумов / Л.М. Рузин, И.Ф. Чупров, О.А. Морозюк, С.М. Дуркин. - Изд. 2-е, перераб. и доп. - М. - Ижевск: Институт компьютерных исследований, 2015. - 480 с.

13. Создание безопасных условий труда в нефтяных шахтах при тепловом воздействии на пласт / Н.Д. Цхадая, А.Е. Жуйков, 3.Х. Ягубов, Э.3. Ягубов // Нефтяное хозяйство. - 2013. - № 9. - С. 121-123.

14. Левин Л.Ю., Семин М.А., Клюкин Ю.А. Оценка эффективности системы распределенной подачи охлажденного воздуха как способа управления микроклиматическими параметрами шахт // Горный информационно-аналитический бюллетень. - 2013. № 12. - C. $185-189$.
15. Зайцев А.В., Семин М.А., Клюкин Ю.А. Исследование критериев нормирования микроклиматических условий в горных выработках // Горный информационно-аналитический бюллетень (научнотехнический журнал). - 2015. - № 12. - С. 151-156.

16. Каратаев А.Ф. Классификация способов, схем и систем вентиляции шахт // Известия Томского политехнического университета. Инжиниринг георесурсов. - 1954. - Т. 79. - С. 17-28.

17. Разработка программно-вычислительного комплекса «АэроСеть» для расчета вентиляционных сетей шахт и рудников / Б.П. Казаков, Ю.В. Круглов, А.Г. Исаевич, Л.Ю. Левин // Горный информационноаналитический бюллетень (научно-технический журнал). - 2006. - № S3. - C. 21-33.

18. Weyburne D. A mathematical description of the fluid boundary layer // Applied Mathematics and Computation. - 2006. - Vol. 175. - P. 1675-1684.

19. Шлихтинг Г. Теория пограничного слоя. М.: Наука, 1974. - 712 с.

20. Hall A.E. Computer techniques for calculating temperature increases in stopes and mine airways // Journal Mine Vent. Soc. of S. Africa. - 1975. - Vol. 28, № 4. - P. 55-59.

21. Lambrechts J. Prediction of wet bulb temperature gradients in mine airways // Journal of the Southern African Institute of Mining and Metallurgy. - 1968. Vol. 68, iss. 8. - P. 372-373.

22. Зайцев А.В. Разработка способов нормализации микроклиматических условий в горных выработках глубоких рудников: дис. ... канд. техн. наук. - Пермь, 2013. - 168 c.

23. Дрейцер Г.А. Нестационарный конвективный теплообмен при турбулентном течении газов и жидкостей в каналах // Теплоэнергетика. - 1998. № 12. - C. 29-38.

24. Arkle K. Use of thermal insulation materials in mines // Jnl. Mine Ventilation Soc. of S. Africa. - 1985. Vol. 38, № 4. - P. 43-45.

25. Baker-Duly C. Design of a large flexible underground refrigeration installation // 4th Int. Mine Ventilation Congress. - Brisbane, 1988. - P. 443-449.

26. Левин Л.Ю., Семин М.А., Зайцев А.В. Разработка математических методов прогнозирования микроклиматических условий в сети горных выработок произвольной топологии // ФТПРПИ. 2014. - № 2. - C. 154-161.

27. Voss J. Control of the mine climate in deep coal mines // Proc. 1st Int. Mine Ventilation Congress. Johannesburg, 1975. - P. 331.

28. Расчет количества воздуха по содержанию кислорода для проветривания рабочих зон при применении 
машин с двигателями внутреннего сгорания / Л.Ю. Левин, А.В. Зайцев, Е.Л. Гришин, М.А. Семин // Безопасность труда в промышленности. - 2015. - № 8. - С. 43-46.

29. Воропаев А.Ф. Теория теплообмена рудничного воздуха и горных пород в глубоких шахтах. M., 1966. $-252 \mathrm{c}$.

30. Семин М.А. Обоснование параметров систем вентиляции рудников в реверсивных режимах проветривания: дис. .... канд. техн. наук. - Пермь, 2016. - 151 с.

31. Hooman K., Ejlali A. Effects of viscous heating, fluid property variation, velocity slip, and temperature jump on convection through parallel plate and circular microchannels // International Communications in Heat and Mass Transfer. - 2010. - Vol. 37, № 1. - P. 34-38. DOI: 10.1016/j.icheatmasstransfer.2009.09.011

32. Щербань А.Н., Кремнев О.А. Научные основы расчета и регулирования теплового режима глубоких шахт: в 2 т. - Киев: Изд-во АН УССР, 1959. - Т. 1. - 430 с.

33. Левин Л.Ю. Теоретические и технологические основы ресурсосберегающих систем воздухоподготовки шахт и рудников: дис. ... д-ра техн. наук. - Пермь: 2010. $-274 \mathrm{c}$.

34. СП 131.13330.2012 Строительная климатология. Актуализированная редакция СНиП 23-01-99. 2012. 97 с.
35. Шалимов А.В. Теоретические основы прогнозирования, профилактики и борьбы с аварийными нарушениями проветривания рудников: дис. ... д-ра техн. наук. - Пермь, 2012. - 329 с.

36. Gibson K.L. The computer simulation of climatic conditions in mines // 15th APCOM Symp. - Brisbane, 1977. - P. 349-354.

37. McAdams W.H. Heat transmission. - 3rd. ed. New York: McGraw-Hill, 1954. - 478 p.

38. Kertikov V. Influence of relative variations along mine workings on air-flow temperature // Proceedings of the 7th International Mine Ventilation Congress. Poland: Research \& Development Center for Electrical Engineering and Automation, 2001. - P. 85-90.

39. Kazakov B.P., Shalimov A.V., Semin M.A. Stability of natural ventilation mode after main fan stoppage // International Journal of Heat and Mass Transfer. - Vol. 86. P. 288-293. DOI: 10.1016/j.ijheatmasstransfer.2015.03.004

40. Mine ventilation and air conditioning / H. Hartman [et al.]. - New York: John Wiley, 1997. - 752 p.

41. New asymptotic heat transfer model in thin liquid films / M. Chhay, D. Dutykh, M. Gisclon, C. Ruyer-Quil // Applied Mathematical Modelling. - 2017. - Vol. 48. P. 844-859.

Please cite this article in English as:

Klyukin Yu.A., Semin M.A., Zaitsev A.V. The experimental study of microclimatic conditions and factors of their formation in the oil mine. Perm Journal of Petroleum and Mining Engineering, 2018, vol.18, no.1, pp.63-75. DOI: 10.15593/2224-9923/2018.3.6

Просьба ссылаться на эту статью в русскоязычных источниках следующим образом:

Клюкин Ю.А., Семин М.А., Зайцев А.В. Экспериментальное исследование микроклиматических условий и факторов их формирования в нефтяной шахте // Вестник Пермского национального исследовательского политехнического университета. Геология. Нефтегазовое и горное дело. - 2018. - Т.18, №1. - С.63-75. DOI: 10.15593/2224-9923/2018.3.6 